Variations tibétaines, Et autres...

\title{
Cécile Ducher, Construction de la tradition biographique de Marpa Chökyi Lodrö
}

\section{(2) OpenEdition \\ Journals}

Édition électronique

URL : https://journals.openedition.org/emscat/1949

DOI : 10.4000/emscat.1949

ISSN : 2101-0013

Éditeur

Centre d'Etudes Mongoles \& Sibériennes / École Pratique des Hautes Études

Référence électronique

"Cécile Ducher, Construction de la tradition biographique de Marpa Chökyi Lodrö », Études mongoles et sibériennes, centrasiatiques et tibétaines [En ligne], 42 | 2011, mis en ligne le 20 décembre 2011, consulté le 13 juillet 2021. URL : http://journals.openedition.org/emscat/1949 ; DOI : https://doi.org/ 10.4000/emscat.1949

Ce document a été généré automatiquement le 13 juillet 2021.

(c) Tous droits réservés 


\section{Cécile Ducher, Construction de la tradition biographique de Marpa Chökyi Lodrö}

\section{RÉFÉRENCE}

Mémoire en Tibétologie pour le Diplôme de l'Ecole Pratique des Hautes Etudes (E.P.H.E.), Ve section, Paris. (148 p. +60 p. d'annexes), soutenue le 24 mars 2011 à Paris. Membres du jury : Matthew Kapstein (directeur de recherches), Charles Ramble (rapporteur), Heather Stoddard (présidente).

\section{Construction de la tradition biographique de Marpa Chökyi Lodrö}

1 L'objectif de ce mémoire est d'explorer la tradition biographique concernant le traducteur tibétain Marpa Chökyi Lodrö (Mar pa chos kyi blo gros). Ce dernier a vécu au IX siècle et est à l'origine de l'une des grandes lignées de transmission bouddhique, la lignée Marpa Kagyü. Nous ne disposons pas de document historique contemporain de ce personnage qui nous permettrait de connaitre précisément ses faits et gestes, mais la présentation de vingt-quatre de ses biographies permet de souligner les liens de filiation entre les différents textes, de faire apparaître les évolutions diachroniques dans les récits et donc de distinguer les ajouts tardifs des motifs classiques. Le mémoire éclaire ainsi d'une lumière indirecte non seulement la vie de Marpa, mais aussi celle des auteurs des biographies le concernant, en mettant en relief quelques-unes de leurs problématiques ainsi que l'utilisation partisane qu'ils font de certains aspects.

2 L'introduction de ce travail présente Marpa et traite des genres hagiographiques et historiques tibétains, des travaux ayant influencé nos recherches et des biographies existantes sur ce grand religieux. Ensuite, l'ouvrage se divise en deux parties. La première vise à décrire chacune des biographies dans l'ordre présumé de leur 
composition, en apportant des informations sur leur auteur, son époque, ses sources et quelques points saillants. Parmi les biographies étudiées, certaines sont particulièrement importantes pour leur rôle dans la construction de la tradition. C'est le cas de celle composée par Ngamdzong Tönpa Bodhirāja (Ngam rdzong ston pa byang chub rgyal po), l'un des disciples de Milarepa (Mi la ras pa), lui-même le disciple le plus connu de Marpa. Cette biographie se trouve dans une collection compilée par Montsepa Kunga Palden (Mon rtse pa Kun dga' dpal ldan 1970, pp. 83-103) et était attribuée à ce dernier par les éditeurs en dépit du colophon mentionnant Bodhirāja. Le texte, qui se présente sous une forme manuscrite extrêmement condensée, fait l'objet d'une édition et d'une traduction intégrale dans les annexes du mémoire ${ }^{1}$. Cette biographie constitue le fondement d'une multitude de récits postérieurs; elle est contemporaine de celle de Gampopa (Sgam po pa 2000, pp. 25-46), un autre disciple de Milarepa, qui est également traduite dans le mémoire.

3 Une autre biographie extrêmement importante dans la genèse de la vita de Marpa est celle qui se trouve dans une collection de biographies de religieux de l'école Drukpa Kagyü ('Brug pa bka' 'gyud) compilée au xix siècle (Inconnu 1970, vol. 1, pp. 149-202). Nous n'avons pu déterminer avec certitude les circonstances de sa composition, mais de nombreux éléments laissent penser qu'elle est ancienne et qu'elle appartient peutêtre aux débuts de la lignée de transmission de la pratique du Demchok Nyengyü (Bde mchog snyan rgyud) transmise par Rechungpa (Ras chung pa), un autre disciple de Milarepa. Elle constituerait ainsi l'origine d'une seconde famille de biographies, dont la plus connue est celle composée au début du XvI siècle par le yogi Tsangnyön Heruka (Gtsang smyon 1970), auteur de la plus célèbre des biographies de Milarepa.

Dans la seconde partie, nous avons sélectionné un certain nombre de points qui nous semblaient significatifs du personnage de Marpa. Certains d'entre eux - l'importance des chants de Marpa dans sa construction biographique, le rôle de Nāropa auprès de Marpa et la relation de ce dernier avec celui qui est souvent décrit comme son rival, Nyö Lotsāwa (Gnyos lo tsā ba) - se sont imposés d'eux-mêmes car certaines biographies les traitent explicitement. Par ailleurs, ils font en Occident l'objet de controverse ou d'intérêt. En ce qui concerne la rencontre de Marpa avec Nāropa, elle est mentionnée dans toutes les biographies bien que son importance ne soit pas toujours aussi centrale que le décrit Tsangnyön Heruka. Les enjeux politiques et religieux entourant le débat, récemment déterré par un chercheur américain (Davidson 2005, pp.141-148), sont discutés dans le mémoire, sur la base de plusieurs textes anciens dans lesquels il apparaît. L'identification de Marpa en tant qu'émanation d'un maître passé et sa pratique du transfert de conscience dans un autre corps (grong 'jug) nous ont ensuite semblé révélateurs des liens de filiation entre les différentes biographies. L'étude de la présence de verbes discursifs extérieurs aux dialogues s'est également imposée dans la mesure où ceux-ci attirent souvent l'attention sur des spécificités de la biographie considérée. Chacun de ces sujets est accompagné d'un tableau récapitulatif. Un dernier point ne faisant l'objet que d'un tableau mais qui ouvre à de futures recherches est la datation de la naissance et de la mort de Marpa. La seule étude de la tradition de Marpa ne permet pas en effet de trancher sur des dates définitives car les divergences sont trop grandes et les dates mentionnées de manière trop tardive.

5 Le travail repose donc sur l'aspect diachronique de la vie de Marpa. Comme le soulignent ses biographies, durant sa vie, il a été considéré avec plus ou moins de suspicion par ses contemporains et n'a connu une véritable célébrité qu'après sa mort. 
Cette gloire s'est développée au fil des générations, au fur et à mesure que sa transmission s'imposait comme centrale dans le bouddhisme tibétain. On a assisté d'abord à l'apparition des biographies centrées sur ses chants ou sur des récits oraux, biographies qui se sont mêlées à d'autres pour dessiner progressivement un personnage vivant, qui s'est rendu en Inde, en est revenu et a eu des disciples. Peu à peu, multiplicité de biographies faisant, des controverses sont également apparues, et de nombreux biographes ont tenté de résoudre des questions sans doute insolubles. Chacun, avec sa problématique propre, fruit de son époque et de son appartenance, a présenté ce qu'il savait de Marpa, ou plutôt ce qu'il voulait que l'on sache. Des disciples dévoués aux érudits héritiers de la tradition, tous ont tissé des fils disparates, qui ont finalement formé un canevas plus vrai que nature. Mais comme tout canevas, son analyse en gros plan en révèle les fils. Ainsi, de même que, d'après les maîtres bouddhistes, lorsque que l'on analyse la réalité on arrive à l'absence de réalité, en analysant la biographie de Marpa, on arrive à son essence, la bénédiction d'une transmission millénaire, mais sans pouvoir en saisir les facettes.

\section{Construction of Marpa Chökyi Lodrö's biographical tradition}

6 The goal of this work is to explore the literary tradition dealing with the life of the Tibetan translator Marpa Chökyi Lodrö (Mar pa Chos kyi blo gros), who lived in the eleventh century and founded one of the great transmission lineages in Tibet, the Marpa Kagyü lineage. No eleventh-century document is available to help us define accurately the life of this historical character, but a critical study of twenty-four of his biographies helps to underline the links between the different texts and reveals the diachronic evolution in the narratives, thus distinguishing between later additions and classical motives. This study thus sheds an indirect light on Marpa's life, and also on the authors of Marpa's biographies, by emphasizing the interests of some of the authors as well as on their use of some tendentious points.

7 After introducing Marpa, Tibetan hagiographic and historic genres, previous scholars' research and the existing biographies on Marpa, the work is divided into two parts. The purpose of the first part is to describe each of the biographies in their presumed order of composition, while commenting on their author, date, sources and main features. Among the biographies, some are particularly important in the construction of the literary tradition. This is the case with the biography written by Ngamdzong Tönpa Bodhirāja (Ngam rdzong ston pa Byang chub rgyal po), one of the disciples of Milarepa (Mi la ras pa), Marpa's best-known disciple. This biography is part of a collection compiled by Montsepa Kunga Palden (Mon rtse pa Kun dga' dpal ldan 1970, pp. 83-103) and was attributed to that author by modern editors, despite a colophon mentioning Bodhirāja. The text, written in an extremely condensed ume calligraphy, has been diplomatically edited and integrally translated in the appendices of the thesis. ${ }^{2}$ This biography lays the foundations for a multitude of later narratives and is contemporary to that of Gampopa (Sgam po pa 2000, pp. 25-46), another of Milarepa's disciples, which is also translated in the thesis.

8 Another extremely important biography in Marpa's biographical genesis is the one found in a collection of biographies of the Drukpa Kagyü ('Brug pa bka' brgyud) lineage compiled in the nineteenth century (Anonymous 1970, vol.1, pp.149-202). The 
circumstances of its composition are not known, but many elements indicate an early date. It possibly belongs to the beginnings of the Demchok Nyengyü (Bde mchog snyan rgyud) lineage transmitted by Rechungpa (Ras chung pa), another of Milarepa's disciples. It would thus constitute the origin of another family of biographies, whose best-known member is the early sixteenth-century work by the yogi Tsangnyön Heruka (Gtsang smyon 1970), author of the most famous biography of Milarepa.

In the second part, I selected a few key points that seemed representative of Marpa. Some points - the importance of Marpa's songs in his biographical construction, Nāropa's role in his life and the relationship of Marpa with the one often described as his rival, Nyö Lotsāwa (Gnyos lo tsā ba) - were obvious choices, as several biographies mention them explicitly and they have been the subjects of controversy or interest in Western scholarship. As far as Marpa's meeting with Nāropa is concerned, all his biographies mention it, even though it isn't always as central as Tsangnyön Heruka describes. The political and religious stakes framing the debate - recently brought to the surface by an American scholar (Davidson 2005, pp. 141-148) - are discussed in the thesis, with references to several works where it appears. The identification of Marpa as an emanation and his practice of transference (grong 'jug) are indicators of the links between biographies and are thus delineated. I also studied the speech indicators other than in dialogues, as they often draw attention to special features of the biography studied. Each one of these topics is accompanied by a summary table. A last point which is only presented with a chart but opens further areas of study concerns the dates of Marpa's birth and death. The study of Marpa's biographical tradition alone is not enough to decide his dates because divergences are too great and they appear so late in biographies.

The work thus deals mainly with the diachronic aspect of Marpa's life. As his biographies show, he was considered more or less circumspectly by his contemporaries. Real fame came after he died, however, and developed with generations, as his transmissions became more central in Tibetan Buddhism. Biographies were first based on his songs and oral traditions; these traditions merged with others to progressively create a lively character, who went to India, came back and had disciples. Step by step, with the manifold versions, controversies also appeared, and many biographers tried to solve probably unending questions. Each author, with his own preoccupations that were the result of his time and tradition, set down what he knew of Marpa, or rather what he wanted to be known. From devoted disciples to knowledgeable heirs of the transmission, all wove varied threads, which finally formed a larger-than-life canvas. As with all canvases, however, a closer study reveals the threads. Thus, in the same way that, according to Buddhist masters, when one analyzes relative reality one reaches its essencelessness, by analyzing Marpa's biography, one reaches its essence, the blessing of a thousand-year-old tradition, without being able to define its facets. 


\section{BIBLIOGRAPHIE}

Davidson, R.

2005 Tibetan Renaissance : Tantric Buddhism in the Rebirth of Tibetan Culture (New York, Columbia University Press), pp. 141-148.

Gtsang smyon he ru ka Rus pa'i rgyan can

1970 Sgra bsgyur mar pa lo tsā'i rnam par thar pa mthong ba don yod (Varanasi, E. Kalsang).

Traduction française de Charrier, C. 2003 Marpa, Maître de Milarépa sa vie, ses chants (Saint-Cannat, Claire Lumière), $227 \mathrm{p}$.

Inconnu

1970 Sgra bsgyur chen po mar pa'i rnam par thar pa, Bka' brgyud gser phreng chen mo [Biographies of Eminent Gurus in the Transmission lineage of teachings of the 'ba' ra dkar brgyud pa sect] (Dehradun, Ngawang Gyaltsen and Ngawang Lungtok), vol. 1, pp. 149-202.

Mon rtse pa Kun dga' dpal ldan

1970 Sgra bsgyur mar pa lo ts+tsha'i rnam par thar pa (nga), Dkar brgyud gser phreng: A Golden Rosary of Lives of Eminent Gurus (Leh, Sonam W. Tashigang), pp. 83-103.

Sgam po pa

2000 Rje mar pa dang rje btsun mi la'i rnam thar, Khams gsum chos kyi rgyal po dpal mnyam med sgam po pa 'gro mgon bsod nams rin chen mchog gi gsung 'bum yid bzhin nor bu (Kathmandu, Ven. Khenpo Shedup Tenzin and Lama Thinley Namgyal), vol. 1, pp. 25-46.

\section{NOTES}

1. Ce texte et sa traduction font l'objet d'une publication à paraître.

2. This text and its translation are the subject of a coming article. 